\title{
Ornithine Decarboxylase Levels in Patients with Normal Colonic Mucosa ${ }^{1}$ )
}

\author{
Elmar Zehnter ${ }^{1}$, Uta Roisch ${ }^{1}$,Wolfgang Kruis ${ }^{2}$, Claudia Breuer $^{1}$ and Volker Diehl ${ }^{1}$ \\ 1 Klinik I für Innere Medizin der Universität zu Köln, Köln, Germany \\ 2 Innere Abteilung, Evangelisches Krankenhaus Köln-Kalk, Köln, Germany
}

Summary: We describe a systematic examination of ornithine decarboxylase activity in 120 colonic mucosal samples which were obtained from 20 subjects without colonic disease to establish the normal mean and standard deviation from proximal to distal colon. Ornithine decarboxylase activity was determined by releasing $\mathrm{CO}_{2}$ from $D L-\left[1-{ }^{14} \mathrm{C}\right]$ ornithine. The mean ornithine decarboxylase levels $\left(\mathrm{CO}_{2}\right.$ liberated) ranged from $0.26 \pm 0.08 \mathrm{nmol} / \mathrm{h} \cdot \mathrm{mg}$ protein in the caecum to $0.44 \pm 0.16 \mathrm{nmol} / \mathrm{h} \cdot \mathrm{mg}$ protein in the rectum. There was no difference between sex and age. Ornithine decarboxylase was not stimulated by guanosine 5'-triphosphate. $\alpha$-Difluoromethylornithine showed an ornithine decarboxylase inhibition of $97.1 \%$. Ornithine decarboxylase activity can be measured with reliable precision and reproducibility. The knowledge of the normal range of ornithine decarboxylase activity in normal human colonic mucosa is necessary for the determination of ornithine decarboxylase activity in pathological findings, especially in malignant transformation.

\section{Introduction}

Ornithine decarboxylase ${ }^{2}$ ) catalyzes the first step in the biosynthesis of polyamines with the formation of putrescine and $\mathrm{CO}_{2}$ from $L$-ornithine utilizing pyridoxal-5phosphate as a cofactor $(1-3)$. Ornithine decarboxylase is a highly regulated enzyme with a very short in vivo half-life of 10-20 minutes (4). It is a key enzyme in the regulation of growth processes and cell proliferation (5). Ornithine decarboxylase is a very minor component of the total soluble protein in most cells and can be induced by a large variety of growth-promoting stimuli such as hormones, growth factors, tissue regeneration activities, drugs and bile acids $(6-10)$. There are existing multiple isoforms of ornithine decarboxylase in mammalian cells (11), of which one isoform can be stimulated by guanosine 5'-triphosphate (GTP) $(12,13)$.

Numerous studies have demonstrated increased and decreased ornithine decarboxylase activities in benign colonic adenomas (14-17) and in colon carcinomas (1723). Ornithine decarboxylase levels have been shown to differ as much as $2-100$ fold between different laboratories (24-26). Studies published until now have not systematically investigated the range of normal levels of ornithine decarboxylase in subjects without or-

\footnotetext{
1) Funding organisation:

The work was supported by a grant from the Frauke WeiskamStiftung. TS 1 136/7/90, Cologne, FRG

2) Enzymes:

Omithine decarboxylase (EC 4.1.1.17)

Omithine-2-oxo-acid aminotransferase (EC 2.6.1.13)
}

ganic intestinal diseases. Without these data, however, the interpretation of ornithine decarboxylase assays in pathological colonic mucosa remains unclear and its use to detect possible malignant transformation must be questionable.

In order to determine a reference range of ornithine decarboxylase activity in different parts of the colon we examined ornithine decarboxylase levels in normally appearing colonic mucosa in male and female subjects of different ages.

\section{Materials and Methods \\ Patients}

Twenty patients ( 11 women, 9 men) aged 17-78 (mean 47.7) years were included in the study. All patients had unclear abdominal symptoms and underwent total colonoscopy. Organic intestinal diseases were excluded. There was also no evidence for systemic diseases such as carcinomas, diabetes, infections, hepatic or renal insufficiency. Blood tests as haemoglobin, erythrocyte sedimentation rate and leukocyte count were normal and there was no history of prior colonic disease. Informed consent was obtained from all subjects according to the Helsinki Declaration.

\section{Biopsy procedures}

The colonic cleansing was performed with senna and Golytely lavage as previously described by Ziegenhagen et al. (27). Biopsies were taken from the caecum, ascending, transverse, descending, sigmoid and rectum by a biopsy forceps (Olympus FB-24Q). Tissue biopsies were placed immediately in liquid nitrogen for ornithine decarboxylase analyses and in formaldehyde for microscopical examination. These biopsies for ornithine decarboxylase analyses were subsequently stored at $-80^{\circ} \mathrm{C}$ until the assay was done during the next three weeks. 
The biopsics were considered to be "normal" when either the endoscopist found normally appearing mucosa and the pathologist did not find any pathological alterations.

\section{Assays}

Homogenization and the assay for ornithine decarboxylase were done as a slight modification of the method of Haarstad et al. (28). The specimens were weighed and homogenized by an ice-cooled Dounce glass/glass homogenizer $1 \mathrm{~g} / 20 \mathrm{ml}$ in homogenizing buffer consisting of $50 \mathrm{mmol} / \mathrm{l}$ Tris buffer $(\mathrm{pH} 7.5), 0.2 \mathrm{mmol} / \mathrm{l}$ pyridoxal5-phosphate, $0.5 \mathrm{mmol} / \mathrm{l}$ ethylenediaminetetraacetate (EDTA), $2 \mathrm{mmol} / \mathrm{l}$ dithiothreitol, $0.2 \mathrm{mmol} / \mathrm{f}$ freshly added phenylmethylsulphonyl fluoride. The homogenates were centrifuged at $46320 \mathrm{~g}$ (Heraeus Biofuge $28 \mathrm{RS}$ ) for $30 \mathrm{~min}$ at $4^{\circ} \mathrm{C}$. The supernatant was inmediately mixed with an equal volume of storage buffer (glycerol, volume fraction $0.84,1 \mathrm{mmol} / \mathrm{l}$ EDTA, $0.4 \mathrm{mmol} / 1$ pyridoxal5 -phosphate and stored at $-20^{\circ} \mathrm{C}$ for subsequent analyzes. This cytosol-glycerol fraction was assayed for omithine decarboxylase activity (protein content $1 \mathrm{~g} / \mathrm{l}$ ).

In 5 specimens an aliquot of the homogenate was also centrifuged for 1 hour at $100000 \mathrm{~g}$ in the ultracentrifuge (Beckman Optima L) and the supernatant was mixed with storage buffer $(1+1)$.

Also in 5 specimens an aliquot of the $46320 \mathrm{~g}$ supernatant was dialyzed overnight at $4{ }^{\circ} \mathrm{C}$ against 100 volumes of homogenization buffer.

Ornithine decarboxylase activity was measured by the release of ${ }^{14} \mathrm{CO}_{2}$ from $D L-\left[1-{ }^{14} \mathrm{C}\right]$ ornithine as previously described by Russell \& Snyder (1) and modified by Haarstad et al. (28) and Löser et al. (29). All measurements were done twice in a tight fitting rubber capped siliconized test tube, fitted with a syringe.

The standard assay mixture contained in a total reaction volume of $200 \mu \mathrm{l}: 30 \mu \mathrm{l}$ cytosol-glycerol fraction (containing $28-32 \mu \mathrm{g}$ protein), $18.5 \mathrm{KBq}(0.5 \mu \mathrm{Ci}) D L-\left[1-^{13} \mathrm{C}\right]$ ornithine hydrochloride (2094.2 GBq/mol $\triangleq 56.6 \mathrm{mCi} / \mathrm{mmol})$ Amersham-Buchler, Braunschweig, Germany, Lot-No: 69) and final concentrations of 46 $\mathrm{mmol} / \mathrm{l}$ Tris $\mathrm{pH} 7.5,0.538 \mathrm{mmol} / \mathrm{l}$ EDTA, $1.85 \mathrm{mmol} / \mathrm{l}$ dithiothreitol and $0.215 \mathrm{mmol} / \mathrm{l}$ pyridoxal-5-phosphate. The released ${ }^{14} \mathrm{CO}_{2}$ was trapped by a piece of Whatman filter paper (No. $1 \mathrm{MM}, 0.65$ $\mathrm{mm}^{2}$ ) impregnated with $25 \mu \mathrm{l}$ of the $\mathrm{CO}_{2}$ trapping agent hyamine hydroxide ( $1 \mathrm{~mol} / \mathrm{h}$ in methanol) (Sigma Inc., Munich). After an incubation time of $60 \mathrm{~min}$ at $37^{\circ} \mathrm{C}$ in a shaking bath the reaction was stopped by injection of $200 \mu \mathrm{l} 6 \mathrm{~mol} / \mathrm{l}$ perchloric acid through the rubber stopper. The incubation was continued routinely for another $30 \mathrm{~min}$ at $37^{\circ} \mathrm{C}$ to ensure complete absorption of ${ }^{14} \mathrm{CO}_{2}$. In 22 cases the incubation was continued for $60 \mathrm{~min}$. The radioactivity on the filter papers was counted with a $\beta$-counter Wallac 1410 (Pharmacia). To avoid chemiluminescence, the papers were counted 24 hours later standing at room temperature in the dark in $10 \mathrm{ml}$ Quickszint 1 (Zinsser Analytic, Frankfurt, Germany). Blanks containing assay buffer alone or with bovine serum albumin in the same concentration as the protein content in the cytosol-glycerol mixture were included.

To be sure that the supernatants are free of mitochondrial ornithine2-oxo-acid aminotransferase ${ }^{2}$ ) which can also release $\mathrm{CO}_{2}$ from ornithine via the glutamate-2-oxo-glutarate pathway the activity of the first 51 enzyme assays were performed also in the presence of final concentrations of $10 \mu \mathrm{mol} / 1$ aminooxyacetate which inhibits the aminotransferase activity without affecting the measurement of ornithine decarboxylase (30). Ornithine decarboxylase activity was also measured in final concentrations of $56 \mu \mathrm{mol} / \mathrm{l} \alpha$-difluoromethylornithine (Merrell Dow Pharma, Rüsselsheim, Germany), an irreversible inhibitor of ornithine decarboxylase (120 biopsies) (31). Furthermore, the ornithine decarboxylase activity was assayed in the presence of GTP in final concentrations of $70 \mu \mathrm{mol} / 1$ (114 biopsies). This is a sensitive method to detect a qualitatively different ornithine decarboxylase isoform $(12,13,32)$. One unit of ornithine decarboxylase activity is defined as the amount releasing $1 \mathrm{nmol}$ of $\mathrm{CO}_{2}$ from $L$-ornithine per hour at $37^{\circ} \mathrm{C}$. Specific activity is expressed as $\mathrm{nmol} \mathrm{CO}_{2}$ per hour per $\mathrm{mg}$ protein, measured in the cytosol-glycerol fractions. Protein analyses were performed in duplicate as described by Bradford (33) using bovine serum albu$\min$ as a standard.

\section{Results}

We examined 120 regional colonic mucosal biopsies, all obtained at standard conditions, for determination of ornithine decarboxylase activity. The enzyme analyses were performed within three weeks. During this time there was no loss of enzyme activity. The ornithine decarboxylase activity in the cytosol-glycerol mixtures remained stable. Some of the extracts $(n=29)$ we have tested several months later still showed the same results (tab. 1).

Enzyme determination (2 replicates) of the same cytosol-glycerol fractions was done with an intra-assay coefficient of $5.0 \%$ in all 120 biopsies, respectively. Different procedures of the supernatant as ultracentrifugation and dialysis did not alter the results. The differences of the ornithine decarboxylase activity of the $46320 \mathrm{~g}$ supernatant and the $100000 \mathrm{~g}$ supernatant were $4.0 \%$. The ornithine decarboxylase activity of the non-dialyzed and the dialyzed cytosol supernatant also showed no significant differences (2.5\%). Due to the lacking effects of ultracentrifugation and dialysis we limited this procedures to the first five specimens. The addition of bovine serum albumin to our assay blank in the same concentration as the protein content in the cytosol-glycerol mixture (about $30 \mu \mathrm{g}$ protein) showed the same result as compared with the assay buffer alone (mean 49 counts/min without bovine serum albumin, 52 counts/min with bovine serum albumin, 5 cytosol-glycerol-fractions tested).

The addition of aminooxyacetate to the first 51 assays of specimens from all six segments from proximal to distal colon showed no difference to those assays without aminooxyacetate $(-3.5 \%$ to $+2.5 \%)$. Thus, our cytosol-glycerol fractions were free from the non-specific

Tab. 1 Effect of storage $\left(-20^{\circ} \mathrm{C}\right)$ of cytosol-glycerol mixture from different biopsies on ornithine decarboxylase activity shown in 9 representative experiments

Ornithine decarboxylase activity

fresh 2 weeks months

(1 day)

\begin{tabular}{llll}
\hline Sigma & 0.67 & 0.66 & \\
Caecum & 0.29 & & 0.27 (3 months) \\
Rectum & 0.29 & 0.28 & 0.26 (6 months) \\
Transverse & 0.51 & 0.53 & 0.51 (2 months) \\
Ascending & 0.24 & & 0.25 (1 month) \\
Rectum & 0.32 & 0.30 & \\
Rectum & 0.58 & 0.61 & \\
Rectum & 0.61 & 0.57 & 0.29 (12 months) \\
Rectum & 0.28 & & \\
\hline
\end{tabular}

Ornithine decarboxylase values are given as ${ }^{14} \mathrm{CO}_{2}$ liberated in $\mathrm{nmol} / \mathrm{h} \cdot \mathrm{mg}$ protein 
ornithine decarboxylase independent formation of ${ }^{14} \mathrm{CO}_{2}$ from $D L-\left[1-{ }^{14} \mathrm{C}\right]$ ornithine by the mitochondrial aminotransferase.

An incubation time longer than 30 min after acidifying the incubation mixture did not influence the results (10 cytosol-glycerol fractions tested).

The mean ornithine decarboxylase levels of all our subjects given as $\mathrm{CO}_{2}$ liberated ranged from 0.26 $\pm 0.08 \mathrm{nmol} / \mathrm{h} \cdot \mathrm{mg}$ protein to $0.44 \pm 0.16 \mathrm{nmol} / \mathrm{h}$. $\mathrm{mg}$ protein and showed a slight increase according to the localization from proximal to distal colon with a considerable variation within each regional group. As also shown in table 2 there were no differences between sex and age.

Ornithine decarboxylase in normal mucosa was not stimulated by GTP. The ornithine decarboxylase activity of the specimens with GTP was on an average 1.01 fold of that without GTP (range from 0.97 to 1.06 ), measured in 114 biopsies. $\alpha$-Difluoromethylornithine reduced the ornithine decarboxylase activity in all 120 biopsies by an average of $97.1 \%(96.5 \%-97.5 \%)$.

\section{Discussion}

We described a level of ornithine decarboxylase activity for normal human subjects whose age overlap with the risk for colorectal cancer. The determination of ornithine decarboxylase activity might be important for the detection of malignant and premalignant diseases of the colon. There are a lot of methodical discrepancies described in different papers $(1,25,26,28,29)$. Different methods and procedures can significantly influence the results. As we could show in our standardized assay, ornithine decarboxylase activity can be measured with reasonable precision and reproducibility.

The addition of glycerol, pyridoxal-5-phosphate and EDTA to the cytosolic supernatant has a protective ef- fect on the storage of the extract if frozen for months at $-20^{\circ} \mathrm{C}(28,29)$. As we could show in some of our experiments, it is not necessary to perform an ultracentrifugation of the homogenate. On the other hand the centrifugation procedure described by Garewal et al. (34): $5 \mathrm{~min}$ at $10000 \mathrm{~g}$, does not seem sufficient to eliminate all mitochondria. Therefore, mitochondrial ornithine decarboxylase activity and especially mitochondrial aminotransferase activity can influence the results. Due to our measurements in presence and absence of aminooxyacetate, an inhibitor of mitochondrial aminotransferase, we could show that our procedure is sufficient and that our results reflect the activity of the cytosolic active ornithine decarboxylase only.

Dialysis of the homogenate was suggested for the elimination of endogenous ornithine, or the small protein antizyme (35) which possibly could dilute the radioactive assay or inhibit the reaction. As we could show, there was no difference between the dialyzed and the non-dialyzed extracts. Thus, these products are negligible and do not play an important role in the ornithine decarboxylase assay.

The addition of bovine serum albumin to our assay in the same concentration as the protein content in the cytosol-glycerol mixture showed the same result as compared with the assay buffer alone. The protein concentration of about $30 \mu \mathrm{g}$ in our standardized enzyme assay has been high enough for reproducible results. This is also different to the ornithine decarboxylase assay used by Garewal et al. (34).

An $\alpha$-difluoromethylornithine corrected control of the ornithine decarboxylase assay is often recommended. The addition of $\alpha$-difluoromethylornithine as a "background" sample may be acceptable in the ornithine decarboxylase assay of normally appearing mucosa. But using an ornithine decarboxylase assay with extracts from cancer mucosa which is often less inhibited

Tab. 2 Specific ornithine decarboxylase activity from proximal to distal normal colonic mucosa in 20 subjects and differentiated by sex and age

\begin{tabular}{|c|c|c|c|c|c|c|}
\hline & \multicolumn{6}{|c|}{ Ornithine decarboxylase activity } \\
\hline & Caecum & Ascending & Transverse & Descending & Sigmoid & Rectum \\
\hline $\begin{array}{l}\text { All } \\
\quad(n=20)\end{array}$ & $0.26 \pm 0.08$ & $0.27 \pm 0.11$ & $0.31 \pm 0.14$ & $0.35 \pm 0.18$ & $0.40 \pm 0.20$ & $0.44 \pm 0.16$ \\
\hline $\begin{array}{l}\text { Men } \\
\quad(n=9)\end{array}$ & $0.23 \pm 0.08$ & $0.28 \pm 0.11$ & $0.35 \pm 0.14$ & $0.40 \pm 0.21$ & $0.47 \pm 0.19$ & $0.48 \pm 0.15$ \\
\hline $\begin{array}{l}\text { Women } \\
\quad(n=11)\end{array}$ & $0.28 \pm 0.08$ & $0.26 \pm 0.11$ & $0.27 \pm 0.14$ & $0.30 \pm 0.16$ & $0.33 \pm 0.20$ & $0.41 \pm 0.17$ \\
\hline $\begin{array}{l}<50 \text { years } \\
(n=10)\end{array}$ & $0.25 \pm 0.07$ & $0.24 \pm 0.12$ & $0.26 \pm 0.12$ & $0.29 \pm 0.15$ & $0.36 \pm 0.23$ & $0.42 \pm 0.15$ \\
\hline $\begin{array}{l}\geq 50 \text { years } \\
\quad(n=10)\end{array}$ & $0.26 \pm 0.10$ & $0.30 \pm 0.08$ & $0.38 \pm 0.15$ & $0.42 \pm 0.21$ & $0.44 \pm 0.17$ & $0.46 \pm 0.18$ \\
\hline
\end{tabular}

Mean values of ornithine decarboxylase \pm standard deviation are given as ${ }^{14} \mathrm{CO}_{2}$ liberated in $\mathrm{nmol} / \mathrm{h} \cdot \mathrm{mg}$ protein 
by $\alpha$-difluoromethylornithine ((13), and our unpublished data), an $\alpha$-difluoromethylornithine corrected control would give an uncorrect "background" reading. The $\alpha$-difluoromethylornithine inhibition of $97.1 \%$ is also an indicator for the homogenicity of the ornithine decarboxylase measured in normal mucosa. The remaining activity is the result of unspecific decarboxylases. The lower $\alpha$-difluoromethylornithine inhibition rate which was found in some carcinoma tissues (15) was not detectable in our specimens of normal mucosa.

Until now little is known about the intra- and inter-individual variability of ornithine decarboxylase in normal subjects. Our study shows a slight increase of ornithine decarboxylase levels from the caecum towards the rectum. This effect was detectable in 17 of our 20 patients, two showed no increase and one a slight decrease. The reason for this increase remains unclear, an elevated cell

\section{References}

1. Russell DH. Snyder SH. Amine synthesis in rapidly growing tissues: ornithine decarboxylase activity in regenerating rat liver, chick, embryo, and various tumors. Proc Natl Acad Sci USA 1968; 60:1420-7.

2. Pegg AE, Williams-Ashman HG. Biosynthesis of putrescine in the prostate gland of the rat. Biochem J 1968; 108:533-9.

3. Jänne J, Raina A. Stimulation of spermidine synthesis in the regenerating rat liver: relation to increased ornithine decarboxylase activity. Acta Chem Scand 1968; 22:1349-51.

4. Russell DH, Snyder SH. Amine synthesis in regenerating rat liver: extremely rapid turnover of ornithine decarboxylase. Mol Pharmacol 1969; 5:253-62.

5. Cannellakis ES, Viceps-Madore D, Kyriakidis DA, Keller JS. The regulation and function of ornithine decarboxylase and of the polyamines. Curr Top Cell Regul 1979; 15:155-202.

6. Panko WB, Kenney FT. Hormonal stimulation of hepatic ornithine decarboxylase. Biochem Biophys Res Com 1971; 43:346-50.

7. Richman RA, Underwood LE, van Wyk JJ, Voina SJ. Synergistic effect of cortisol and growth hormone on hepatic ornithine decarboxylase activity. Proc Soc Exp Biol Med 1971; 138:880-4.

8. Beck WT, Bellantone RA, Canellakis ES. The in vivo stimulation of rat liver ornithine decarboxylase activity by dibutyryl cyclic adenosine 3',5'-monophosphate, theophylline and dexamethasone. Biochem Biophys Res Commun 1972; 48:164955.

9. Luk GD, Marton LJ, Baylin SB. Ornithine decarboxylase is important in intestinal micosal maturation and recovery from injury in rats. Science 1980; 210:195-8.

10. Takano S, Matsushima M, Ertürk E, Bryan GT. Early induction of rat colonic epithelial ornithine decarboxylase and S-adenosyl-L-methionine decarboxylase activities by N-Methyl-N'-nitro-N-nitrosoguanidine or bile salts. Cancer Res 1981; 41:624-8.

11. Richards JF, Janzen A, Peng T, Strumpfer A. Function and origin of multiple ionic forms of hormone-induced ornithine decarboxylase. Arch Biochem Biophys 1993; 300:80-7.

12. O'Brien TG, Madara T, Pyle JA, Holmes M. Ornithine decarboxylase from mouse epidermis and epidermal papillomas: differences in enzymatic properties and structure. Proc Natl Acad Sci $1986 ; 83: 9448-52$.

13. Sumiyoshi H, Baer AR, Wargovich MJ. Heterogenicity of ornithine decarboxylase during mouse colon carcinogenesis and in human colon tumors. Cancer Res 1991; 51:2069-72. turnover in the distal parts of the colon might play a role. No difference according to age and sex could be found. In contrast to our findings the results of Hixson et al. $(23,36)$ showed no variation in the ornithine decarboxylase activity with bowel location. He measured the ornithine decarboxylase activity in apparently unaffected colorectal mucosa but with known neoplastic lesions. The interpretation as "normal" colonic mucosa must therefore be questionable.

The presence of a GTP activatable ornithine decarboxylase which is described in carcinoma tissue $(12,13,32)$ could not be found in normal colonic mucosa.

\section{Acknowledgements}

The excellent technical assistance of Ilse Drewes-Merker is gratefully acknowledged. We thank Merrell Dow Pharma Inc., Rüsselsheim, Germany for the generous gift of $\alpha$-difluoromethylornithine.

14. Luk GD, Baylin SB. Ornithine decarboxylase as a biological marker in familial colonic polyposis. New Engl J Med 1984; 311:80-3.

15. Mc Garrity TJ, Pfeiffer BS, Bartholomew MJ, Pegg AE. Colonic polyamine content and ornithine decarboxylase activity as markers for adenomas. Cancer 1990; 66:1539-43.

16. Narisawa $T$, Takahashi $M$, Niwa $M$, Koyama $H$, Kotanagi $H$, Kusaka $\mathrm{N}$, et al. Increased mucosal ornithine decarboxylase activity in large bowel with multiple tumors, adenocarcinoma, and adenoma. Cancer 1989; 63:1572-6.

17. Lans JI, Jaszewski R, Arlow FL, Tureaud J, Luk GD, Majumdar APN. Supplemental calcium suppresses colonic mucosal ornithine decarboxylase activity in elderly patients with adenomatous polyps. Cancer Res 1991; 51:3416-9.

18. Pegg AE. Polyamine metabolism and its importance in neoplastic growth and as a target for chemotherapy. Cancer Res 1988; 48:759-74.

19. Porter CW, Herrera-Ornelas L, Petra P, Petrelli NF, Mittelman A. Polyamine biosynthetic activity in normal and neoplastic human colorectal tissues. Cancer 1987; 60:1275-81.

20. Nishioka H, Grossie B, Chang TH, Ajani JA, Ota DM. Colorectal omithine decarboxylase activity in human mucosa and tumors: elevation of enzymatic activity in distal mucosa. J Surg Oncol 1991; 47:117-20.

21. Koo HB, Sigurdson ER, Daly JM, Berenson M, Grashen S, Decosse JJ. Ornithine decarboxylase levels in the rectal mucosa of patients with colonic neoplasia. J Surg Oncol 1989; 38:240-3.

22. Berdinskikh NK, Ignatenko NA, Zaletok SP, Ganina KP, Chorniy VA. Ornithine decarboxylase activity and polyamine content in adenocarcinomas of human stomach and large intestine. Int J Cancer 1991; 47:496-8.

23. Hixson LJ, Garewal HS, McGee DL, Sloan D, Fennerty MB, Sampliner RE, et al. Ornithine decarboxylase and polyamines in colorectal neoplasia and mucosa. Cancer Epidemiol Biomarkers Prev 1993; 2:369-74.

24. Braverman DZ, Stankiewicz H, Goldstein R, Patz JK, Morali GA, Jacobsohn WZ. Ornithine decarboxylase: an unreliable marker for the identification of population groups at risk for colonic neoplasia. Am J Gastroenterol 1990; 85:723-6.

25. Moorehead J, Hoper M, McKelvey STD. Assessment of ornithine decarboxylase activity in rectal mucosa as a marker for colorectal adenomas and carcinomas. Br J Surg 1987; $74: 364-5$. 
26. Love RR, Verma AK, Surawicz TS, Morrissey JF. Colon ornithine decarboxylase activity following standard endoscopy preparation regimens. J Surg Oncol 1989; 42:150-3.

27. Ziegenhagen DJ, Zehnter E. Tacke W, Kruis W. Addition of senna improves colonoscopy preparation with lavage: a prospective randomized trial. Gastrointest Endosc 1991; 37:547-9.

28. Haarstad H, Winnberg A, Petersen H. Effects of a cholecystokinin-like peptide on DNA and polyamine synthesis in the rat pancreas. Scand J Gastroenterol 1985; 20:530-8.

29. Löser C, Fölsch UR, Cleffmann U, Nustede R, Creutzfeldt W. Role of ornithine decarboxylase and polyamines in camostate (Foy-305)-induced pancreatic growth in rats. Digestion 1989; 43:98-112.

30. Murphy BJ, Brosnan ME. Subcellular localization of ornithine decarboxylase in liver of control and growth-hormone-treated rats. Biochem J 1976; 157:33-9.

31. Metcalf BW, Bey P, Danzin C, Jung MJ, Casara P, Vevert JP. Catalytic irreversible inhibition of mammalian ornithine decarboxylase by substrate and product analogues. J Am Chem Soc 1978; 100:2551-3.

32. Hietala OA, Yum KY, Pilon J, O'Donnell $K$, Holroyde $C P$, $\mathrm{Kline} \mathrm{I}$, et al. Properties of ornithine decarboxylase in human colorectal adenocarcinomas. Cancer Res 1990; 50:2088-94.
33. Bradford MM. A rapid and sensitive method for the quantitation of microgram quantities of protein utilizing the principle of protein-dye binding. Anal Biochem 1976; 72:248-54.

34. Garewal HS, Sloan D, Sampliner RE, Fennerty B. Ornithine decarboxylase assay in human colorectal mucosa. Methodological issues of importance to quality control. Int $\mathrm{J}$ Cancer 1992; 52:355-8.

35. Fong WF, Heller JS, Canellakis ES. The appearance of an ornithine decarboxylase inhibitory protein upon the addition of putrescine to cell cultures. Biochim Biophys Acta 1976; 428:456-65.

36. Hixson LJ, Emerson SS, Shassetz LR, Gerner EW. Sources of variability in estimating ornithine decarboxylase activity and polyamine contents in human colorectal mucosa. Cancer Epidemiol Biomarkers \& Prev 1994; 3:317-23.

Received November 29, 1995/April 15, 1996

Corresponding author: Prof. Dr. Wolfgang Kruis, Chefarzt der Inneren Abteilung, Evangelisches Krankenhaus Kalk, Buchforststraße 2, D-51103 Köln, Germany 
